Article

\title{
McLuhan's Philosophy of Media Ecology: An Introduction
}

\author{
Robert K. Logan \\ University of St. Michael's College and Department of Physics, University of Toronto, 60 St. George, Toronto, \\ ON M5S 1A7, Canada; logan@physics.utoronto.ca
}

Academic Editor: Marcin J. Schroeder

Received: 17 June 2016; Accepted: 25 July 2016; Published: 1 August 2016

\begin{abstract}
This essay will serve as an introduction to the collection of essays in this Special Issue of MDPI Philosophies that will explore the philosophical roots of Marshall McLuhan's study of media and the field of media ecology that followed in its wake.
\end{abstract}

Keywords: McLuhan; media; technology; communications; ecology; effect; figure; ground; the medium is the message

PACS: J0101

\section{What Is Philosophy?}

Marshall McLuhan was a scholar of technology, media, and communications whose work gave rise to the field of media ecology. In this essay, we will describe McLuhan's practice of media ecology, which implicitly contains McLuhan's philosophy of media ecology. The reader might ask what the philosophy of media ecology is. The philosophy of media ecology parallels the plethora of specialized philosophies that go by the name of the Philosophy of $X$ where $X$ can be nature or science, for example, as in the philosophy of nature or the philosophy of science. Here is a list of Xs for which there exists a body of philosophy that goes by the name of the Philosophy of $X$, where, in alphabetical order, $\mathrm{X}$ can be aesthetics, artificial intelligence, biology, cognition, communication, computation, consciousness, culture, economics, education, evolution, fine art, history, information, language, law, literary criticism, literary form, mathematics, mind, nature, psychology, religion, rhetoric, science, social science, symbolic forms or technology. The list is by no means exhaustive. There is even a philosophy of philosophy or metaphilosophy that studies the nature of philosophy.

However, let us stop for a moment and examine what we mean by philosophy. The term comes from the ancient Greeks where 'philo' means love and 'sophos' means wisdom and hence philosophy is the love of wisdom. Philosophy has come to have a slightly different meaning in that it denotes an academic practice or study. In fact, the term philosophy cannot be defined precisely because the subject is so complex (sciphilos.info/docs_pages/docs_Philosophy_defined_css.html) [1] and also quite often so controversial. Here is a collection of definitions that will help us make sense of the term, philosophy. Each will prove helpful in helping us to understand McLuhan's philosophy of media ecology.

The two definitions that comes closest to describing McLuhan's philosophy of media ecology are:

The critical study of the basic principles and concepts of a discipline (www.collinsdictionary.com/dictionary/english/philosophy) [2].

The study of the fundamental nature of knowledge, reality, and existence, especially when considered as an academic discipline. (www.oxforddictionaries.com/ definition/english/philosophy) [3] 
The following definitions of philosophy contain the idea of the above two definitions but they also introduce the notion of conduct, religion or the meaning of life.

The rational investigation of the truths and principles of being, knowledge, or conduct. (Dictionary.com) [4].

The study of ideas about knowledge, truth, the nature and meaning of life, etc. (www.merriam-webster.com/dictionary/philosophy) [5].

The study of the basic ideas about knowledge, truth, right and wrong, religion, and the nature and meaning of life (www.wordcentral.com/cgi-bin/student?va=philosophy) [6].

\section{McLuhan's Philosophy of Media Ecology Is Not a Form of Moral Philosophy}

Marshall McLuhan was a devout Roman Catholic, a very religious person who attended church and read the Bible daily but he never allowed his private convictions to enter into his scholarship. His study of media ecology does not deal with values or moral issues as these remarks from Understanding Media demonstrate.

A moral point of view too often serves as a substitute for understanding in technological matters. (McLuhan, 1964 [7], p. 216).

Is it not obvious that there are always enough moral problems without also taking a moral stand on technological grounds? [...] Print is the extreme phase of alphabet culture that detribalizes or decollectivizes man in the first instance. Print raises the visual features of alphabet to highest intensity of definition. Thus print carries the individuating power of the phonetic alphabet much further than manuscript culture could ever do. Print is the technology of individualism. If men decided to modify this visual technology by an electric technology, individualism would also be modified. To raise a moral complaint about this is like cussing a buzz-saw for lopping off fingers. "But", someone says, "we didn't know it would happen." Yet even witlessness is not a moral issue. It is a problem, but not a moral problem; and it would be nice to clear away some of the moral fogs that surround our technologies. It would be good for morality. (McLuhan, 1962 [8], p. 158).

McLuhan (1969) [9] in his Playboy interview was quite explicit about his refusal to moralize:

For many years, until I wrote my first book, The Mechanical Bride, I adopted an extremely moralistic approach to all environmental technology. I loathed machinery, I abominated cities, I equated the Industrial Revolution with original sin and mass media with the Fall. In short, I rejected almost every element of modern life in favor of a Rousseauvian utopianism. But gradually I perceived how sterile and useless this attitude was, and I began to realize that the greatest artists of the 20th Century-Yeats, Pound. Joyce, Eliot-had discovered a totally different approach, based on the identity of the processes of cognition and creation. I realized that artistic creation is the playback of ordinary experience-from trash to treasures. I ceased being a moralist and became a student ...

The world we are living in is not one I would have created on my own drawing board, but it's the one in which I must live, and in which the students I teach must live. If nothing else, I owe it to them to avoid the luxury of moral indignation or the troglodytic security of the ivory tower and to get down into the junk yard of environmental change and steam-shovel my way through to a comprehension of its contents and its lines of force-in order to understand how and why it is metamorphosing man ...

Cataclysmic environmental changes are, in and of themselves, morally neutral; it is how we perceive them and react to them that will determine their ultimate psychic and social consequences. 


\section{McLuhan as Social Critic}

So if McLuhan was not interested in moralizing what was his philosophy of media ecology all about. McLuhan was a social critic. He wanted to make us aware of the subliminal effects of technology and media. In Understanding Media, he wrote: "I am in the position of Louis Pasteur telling doctors that their greatest enemy was quite invisible, and quite unrecognized by them (McLuhan, 1964 [7], p. 32)." He also wanted to warn us of the negative impacts of technology through the study of media ecology. "Is it not possible to emancipate ourselves from the subliminal operation of our own technologies? Is not the essence of education civil defense against media fallout? (McLuhan, 1962 [8], p. 294)."

McLuhan believed that by studying media and their effects that one could anticipate change and be prepared for it. "Control over change would seem to consist in moving not with it but ahead of it (McLuhan, 1964 [7], p. 179)."

\section{Media and Technology Are Interchangeable in McLuhan's Philosophy of Media Ecology}

Note that McLuhan uses the terms technology and media interchangeably. He talks of print as "the technology of individualism" but then refers to "media fallout" (McLuhan, 1962 [8], p. 193). To understand McLuhan philosophy of media ecology, it is essential to understand that media are technologies and technologies are media. McLuhan regards all technologies and all tools as media. The term media is most often used in common practice solely to refer to communication media. For McLuhan, a chair is as much a medium as is a newspaper. The content of the chair is the person sitting in it, whereas the content of the newspaper is its news stories and its advertisements. In Understanding Media, McLuhan (1964) [7] analyzed many different communication media ranging from the spoken and written word to radio, movies, television and computers as well as comics and ads. However, he also analyzed a number of technological tools that are not considered to be communication media such as the wheel, the bicycle, the motorcar, roads, houses, clothing, clocks, the airplane, and weapons. All media with the exception of the spoken word involved some human artifact or technology. For McLuhan, "technology" includes hardware, software and all forms of organization. A technology or medium is any artifact or methodology that mediates between a human user and his or her environment where the environment includes the physical, biological and social dimensions of human interactions. The fact that computers are referred to as information technology supports the notion that the distinction between media and technology is an artificial one. A computer is both a technology and a medium of communication as is the case with paper, the pen, the telephone, radio, television and computers.

Every medium/technology independent of its content has its own unique effects, which is what McLuhan called its message in his most memorable one-liner of all: "the medium is the message" [7], but more of that later.

For McLuhan media include all the tools, technologies and communication systems by which human interact with each other and hence mediate their physical, biological, cultural, social and economic environments. The mediasphere of all human tools, technologies and communication systems is unplanned-it self-organizes itself and evolves like the biosphere through the interactions of individual inventors and users with their media. The mediasphere evolves in the same Darwinian pattern of descent, modification and selection, as is the case with the evolution of living organisms since every medium, technology or tool is a combination of some combination of prior media, tools and technologies. Like the biosphere the mediasphere has no endpoint it constantly probes the adjacent possible as described by Stuart Kauffman (2000) [10] and like the biosphere its complexity continues to increase. 


\section{Why Does McLuhan's Philosophy of Media and Communication Studies Entail the Notion of Media Ecology? Why Ecology?}

A new medium is never an addition to an old one, nor does it leave the old one in peace. It never ceases to oppress the older media until it finds new shapes and positions for them (McLuhan, 1964 [7], p. 158).

In other words, media are part of a media ecosystem and they interact with each other. McLuhan's study of media and communications has come to be regarded as media ecology because McLuhan expressed his insights in terms of environments and ecology as is revealed by the following quotes where the bold text emphasis is mine.

The electric age is the age of ecology. It is the study and projection of the total environments of organisms and people, because of the instant coherence of all factors, made possible by moving information at electric speeds (McLuhan, 1969 [11], p. 36).

Since Sputnik and the satellites, the planet is enclosed in a manmade environment that ends "Nature" and turns the globe into a repertory theater to be programmed (McLuhan \& Watson, 1970 [12], p. 9).

All of the new media have enriched our perceptions of language and older media. They are to the man-made environment what species are to biology. (McLuhan, 1969 [11], p. 84).

Media, by altering the environment, evoke in us unique ratios of sense perception. When these ratios change, men change.

Environments work us over and remake us. It is man who is the content of and the message of the media, which are extensions of himself. Electronic man must know the effects of the world he has made above all things. (McLuhan \& Nevitt, 1972 [13], p. 90).

It is perfectly clear to me that all media are environments. As environments, all media have all the effects that geographers and biologists have associated with environments in the past ... the medium is the message because the environment transforms our perceptions governing the areas of attention and neglect alike ecology does not seek connections, but patterns. (McLuhan, 1970 [14], p. 4).

Each new medium is a cliché that burrows and borrows and barrows, or dumps, earlier clichés. Media as environments are quotation devices, as it were-they hook and scrap and hoick all at once. (Letter from McLuhan to John Wain, 8 December 1970 retrieved from the McLuhan Archive in the National Library in Ottawa Canada. [15]).

All media of communications are clichés serving to enlarge man's scope of action, his patterns of associations and awareness. These media create environments that numb our powers of attention by sheer pervasiveness. (McLuhan \& Watson, 1970 [12], p. 57).

In an interview, McLuhan was asked, "What now, briefly, is this thing called media ecology." McLuhan responded,

It means arranging various media to help each other so they won't cancel each other out, to buttress one medium with another. You might say, for example, that radio is a bigger help to literacy than television, but television might be a very wonderful aid to teaching languages. And so you can do some things on some media that you cannot do on others. And, therefore, if you watch the whole field, you can prevent this waste that comes by one canceling the other out (McLuhan, 2004 [16], p. 271). 
When McLuhan (1995 [17], p. 275) talks of "media as environments" we should remember that for him environments have an ecological connotation, as the following 1967 quote indicates: "Environments are not just containers; but are processes that change the content totally (McLuhan, E. \& Zingrone, 1995 [18], p. 275)."

McLuhan and I used the term "media ecology" in Chapter 1 of our book The Future of the Library: From Electric Media to Digital Media:

The traditional library a monument to hardware, now finds itself in the new electronic age of instantaneous information, an age of software \{and two-way interactive digital media\}. The libraries response to this challenge has been to go multimedia. It is fighting back with audio tapes and discs, video tapes, films, music concerts, plays, art galleries, computer terminals and centers for continuing study. In short the library is becoming a center for media ecology instead of remaining more tied to the culture of the book.

Do the media tend to push out literacy and the intellectual activity upon which our culture is based? Or is the effect of the mass media only to provide a form of entertainment for the masses, who would not participate in the intellectual development of their culture anyway? One might also ask do these media in fact create a culture superior to the past and more suited to our present condition of material well-being? These are questions that require careful study by media ecology by librarians, educators, communicators and all those concerned with the preservation of our cultural heritage (Logan and McLuhan, 2016 [19], pp. 5, 72-73).

Although McLuhan might have originated the term "media ecology" or at least tied media to ecology, it is certainly the case that it was the writings and pedagogy of Neil Postman (1993) [20] that gave currency to the term media ecology. The formation of the Media Ecology Association (www.media-ecology.org) has been instrumental in the preservation and propagation of this tradition and the development of media ecology as a discipline.

The introduction of the term ecology into what had been called media studies or communication studies signaled the fact that the study of media by media ecologists was not merely a study of the content of media. Rather, media ecology entails a study of the social, cultural and psychic impacts of media, independent of their content, thus embracing McLuhan's defining one-liner: the medium is the message.

\section{The Interdisciplinary Character of McLuhan's Philosophy of Media Ecology}

McLuhan's use of terms like environment and ecology borrowed from biology represents an integral part of McLuhan's philosophical approach that encompasses a generalist's approach of interdisciplinarity or multidisciplinarity. The depth and learning of the expert is valued as long as it does not exclude the learning and ideas of other experts. The tunnel vision of the specialist, however, is to be avoided. "The specialist is one who never makes the smallest mistakes, while moving toward a grand fallacy (McLuhan, 1964 [7], p. 118)."

The multidisciplinary approach is the only way to get at the large patterns of the interplay between a society and its technologies. "Any subject taken in depth at once relates to other subjects (McLuhan, 1964 [7], p. 301)."

The effects of electric information patterns naturally reinforce the multidisciplinary approach of McLuhan.

Electric media, because of their total "field" character, tend to eliminate the fragmented specialties of form and function that we have long accepted as the heritage of alphabet, printing, and mechanization (McLuhan, 1964 [7], p. 243).

Electric technology ends the old dichotomies between culture and technology, between art and commerce and between work and leisure ([7], p. 301). 
One can extend McLuhan's notion that media interact with each other to his belief that disciplines also interact with each other given that a discipline is a medium. Riffing on his remark that new media oppress older media, I created a reason why interdisciplinarity is such an integral part of the philosophy of media ecology:

"A new discipline is never an addition to the older disciplines, nor does it leave the old ones in peace. It never ceases to oppress the older disciplines until it finds new shapes and positions for them (McLuhan, 1964 [7], p. 158 with the word 'medium' replaced with 'discipline,' which has been bolded)."

This is why a multidisciplinary approach for McLuhan is the only way to explore any given field of knowledge. McLuhan's understanding that a multidisciplinary non-specialist approach is the only way to create new knowledge parallels his notion of the effects of media on each other and that to understand any medium one has to understand all the media that it interacts with.

Artists played a particularly important role in McLuhan's interdisciplinary approach to understanding media. McLuhan's definition of an artist is quite broad and includes scientists. "The artist is the man in any field, scientific or humanistic, who grasps the implications of his actions and of new knowledge in his own time. He is the man of integral awareness" (McLuhan, 1964 [7], p. 71).

\section{Anti-Environments}

"I don't know who discovered water but it wasn't a fish"—a line used often by McLuhan that he attributed to an anonymous source.

McLuhan asserted that all media create service and disservice environments and that these environments are largely subliminal to the majority of media users. It is only by an artist(s) creating an anti-environment that we become aware of the environment created by a technology or medium.

Art as an anti-environment is an indispensable means of perception, for environments, as such, are imperceptible. (McLuhan, 2005 [21], Vol. 3, 20).

The role of the artist is to create an Anti-environment as a means of perception and adjustment. Without an Anti-environment, all environments are invisible (McLuhan \& Carson, 2003 [22], pp. 30-33).

Professionalism is environmental. Amateurism is anti- environmental. Professionalism merges the individual into patterns of total environment. Amateurism seeks the development of the total awareness of the individual and the critical awareness of the ground rules of society. The amateur can afford to lose. The expert stays put (McLuhan \& Fiore, 1970 [23], p. 93).

Any new technology, any extension or amplification of human faculties given material embodiment, tends to create a new environment. It is in the interplay between the old and new environments that there is generated an innumerable series of problems and confusions. It is useful to view all the arts and sciences as acting in the role of anti-environments that enable us to perceive the environment (McLuhan \& Parker, 1968 [24], p. 243).

\section{Knowledge Ecology}

Not only are media part of an ecosystem giving rise to media ecology but knowledge systems/disciplines also interact with each other and give rise to a knowledge ecosystem that can only be navigated with an interdisciplinary approach.

McLuhan developed the notion that media create an environment or an ecosystem that is best studied by what we now call media ecology, a term that he also embraced. Paralleling his notion of a 
media ecosystem was his notion of a knowledge ecosystem in which the study of one discipline in depth required one crossing disciplinary boundaries to study other disciplines as well. Although McLuhan never used the term "knowledge ecosystem" I would like to introduce it along with the idea of a "knowledge ecology" based on McLuhan's notion of the interdisciplinarity of knowledge.

These quotes from Understanding Media (McLuhan, 1964) [7] to my mind introduce the notion of a knowledge ecosystem (all knowledge is interrelated) and knowledge ecology or the study of interdisciplinarity.

In education, likewise, it is not the increase in numbers of those seeking to learn that creates the crisis. Our new concern with education follows upon the changeover to an interrelation in knowledge, where before the separate subjects of the curriculum had stood apart from each other. Departmental sovereignties have melted away as rapidly as national sovereignties under conditions of electric speed ([7], p. 47).

Men are suddenly nomadic gatherers of knowledge, nomadic as never before-but also involved in the total social process as never before; since with electricity we extend our central nervous system globally, instantly interrelating every human experience ([7], pp. 310-311).

This excerpt from the famous March1969 Playboy interview reveals that McLuhan (1969) [9] believed the acquisition of knowledge not only required crossing disciplinary boundaries but also required accessing knowledge in a variety of media:

PLAYBOY: Might it be possible for the "TV child" to make the adjustment to his educational environment by synthesizing traditional literate-visual forms with the insights of his own electric culture-or must the medium of print be totally unassimilable for him?

McLuhan: Such a synthesis is entirely possible, and could create a creative blend of the two cultures-if the educational establishment was aware that there is an electric culture. In the absence of such elementary awareness, I'm afraid that the television child has no future in our schools.

\section{Philosophical, Intellectual, Artistic, and Scientific Roots of Marshall McLuhan's Thinking}

This topic deserves an essay on its own but since this first essay in the collection is intended to serve as the first introduction to the philosophy and philosophical roots of Marshall McLuhan I will do a quick survey of the intellectual roots of McLuhan's thinking. As the title suggests that are four basic streams that contributed to McLuhan's philosophy of Media Ecology. They are (1) the philosophical roots of primarily Aristotle and Vico; (2) the scholarly roots of Siegfried Gidieon, Lewis Mumford, I.A. Richards, Harold Innis, Hans Selye and Edward Hall; (3) the artist/literary roots of James Joyce, Wyndham Lewis, Ezra Pound, T.S. Eliot and the symbolist poets and (4) the scientific roots of electrodynamics, relativity theory, quantum mechanics, ecology and psychology. McLuhan was extremely well read and the many authors who influenced him are much too numerous to mention in this article or even in this Special Issue. To gain a partial scope of the range of readings that influenced McLuhan the reader is directed to McLuhan's reading list that he compiled for his students which can be found on pages 397 to 401 in the book Essential McLuhan edited by his son Eric McLuhan and Frank Zingrone (1995) [18].

Conflicts of Interest: The author declares no conflict of interest.

\section{References and Notes}

1. Science and Philosophy. Available online: sciphilos.info/docs_pages/docs_Philosophy_defined_css.html (accessed on 10 January 2016). 
2. Collins. Philosophy. Available online: http://www.collinsdictionary.com/dictionary/english/philosophy (accessed on 10 January 2016).

3. Oxford Dictionaries. Philosophy. Available online: http://www.oxforddictionaries.com/definition/english/ philosophy (accessed on 10 January 2016).

4. Dictionary.com, LLC. Available online: Dictionary.com (accessed on 10 January 2016).

5. Merrian-Webster. Philosophy. Available online: www.merriam-webster.com/dictionary/philosophy (accessed on 10 January 2016).

6. Merrian-Webster. Word Central. Available online: www.wordcentral.com/cgi-bin/student?va=philosophy (accessed on 10 January 2016).

7. McLuhan, M. Understanding Media: Extensions of Man; Mentor: New York, NY, USA, 1964. (The page references in the text are for the Mentor paperback second edition. Readers should be aware that the pagination in other editions is different. To aid the reader in calibrating note that Chapter 1 The Medium is the Message begins on page 23 in the edition I have referenced.)

8. McLuhan, M. Gutenberg Galaxy: The Making of Typographic Man; University of Toronto Press: Toronto, ON, Canada, 1962.

9. McLuhan, M. Playboy Magazine Interview; Playboy Magazine: New York, NY, USA, 1969.

10. Kauffman, S. Investigations; Oxford University Press: Oxford, UK, 2000.

11. McLuhan, M. Counterblast; McClelland and Stewart: Toronto, ON, Canada, 1969.

12. McLuhan, M.; Watson, W. From Cliché to Archetype; Viking: New York, NY, USA, 1970.

13. McLuhan, M.; Nevitt, B. Take Today: The Executive as Dropout; Longman Canada: Toronto, ON, Canada, 1972.

14. McLuhan, M. Education in the Electronic Age; Springer: Amsterdam, The Netherlands, 1970; Interchange/Volume 1, No. 4; pp. 1-12.

15. Letter from Marshall McLuhan to John Wain, 8 December 1970 retrieved from the McLuhan Archive in the National Library in Ottawa Canada.

16. McLuhan, M. Understanding Me: Lectures and Interviews; McLuhan, S., Staines, D., Eds.; MIT Press: Cambridge, MA, USA, 2004.

17. McLuhan, M. A McLuhan Sourcebook. In Essential McLuhan; McLuhan, E., Zingrone, F., Eds.; Anansi: Concord, ON, Canada, 1995.

18. McLuhan, E., Zingrone, F., Eds.; Essential McLuhan; Anansi: Concord, ON, Canada, 1995.

19. Robert, L.; McLuhan, M. The Future of the Library: From Electric Media to Digital Media; Peter Lang Publishing: New York, NY, USA, 2016.

20. Postman, N. Technopoly: The Surrender of Culture to Technology; Vintage Books: New York, NY, USA, 1993.

21. McLuhan, M. Marshall McLuhan Unbound; Ginko Press: Berkeley, CA, USA, 2005.

22. McLuhan, M.; Carson, D. The Book of Probes; Ginko Press: Berkeley, CA, USA, 2003.

23. McLuhan, M.; Fiore, Q. The Medium is the Message; Bantam Books: New York, NY, USA, 1970.

24. McLuhan, M.; Parker, H. Through the Vanishing Point: Space in Poetry and Painting; HarperCollins: New York, NY, USA, 1968.

(C) 2016 by the author; licensee MDPI, Basel, Switzerland. This article is an open access article distributed under the terms and conditions of the Creative Commons Attribution (CC-BY) license (http://creativecommons.org/licenses/by/4.0/). 